DOI: 10.15290/bsp.2017.22.04.13

Piotr Sobański

Uniwersytet Śląski

piotr.sobanski@yahoo.com

\title{
Uwagi na temat zaliczenia darowizn i zapisów windykacyjnych na schedę spadkową
}

\author{
Remarks about the Inclusion of Donations and Specific Bequests \\ in the Inherited Share
}

\begin{abstract}
This article discusses the problematic aspects related to the inclusion of donations and specific bequests in the inherited share, provoking controversy in legal doctrine and judicial practice. The author presents specific issues in detail, and then goes on to express his view on each of them. The comments on the adjustment to Article 1039 of the Civil Code are not only proposals de lege lata, some are proposals de lege ferenda. Although the provision of the inclusion of donations and specific bequests in the inherited share does not seem to require immediate attention from the Polish legislator, there are many rational arguments for the above-mentioned adjustment. There are several courses of action for the possible future amendment to Article 1039 of the Civil Code: removing the obligation for the inclusion of donations and specific bequests in the inherited share or reversing the mechanism of the law in question by assuming that donations and specific bequests will be subject to inclusion only under the testator's will. It is also conceivable that the amendment would be small, and would take into consideration the comments made in this article.
\end{abstract}

Keywords: donation, specific bequest, succession law, division of the estate

Słowa kluczowe: dział spadku, zaliczenie na schedę, spadki, darowizna, zapis windykacyjny

\section{Wstęp}

Zgodnie z wolą ustawodawcy, wspólność powstająca wskutek dziedziczenia ma mieć z założenia jedynie charakter przejściowy. Sposób uregulowania wzajemnych relacji pomiędzy osobami spadkobierców w ustawodawstwach, w których przyjęta została koncepcja sukcesji uniwersalnej, nie jest jednolity. Stosowane są zarówno systemy współwłasności ułamkowej (np. we Francji, art. 1220 i 883 francuskiego kc.), 
systemy współwłasności łącznej (np. w Niemczech oraz Austrii, \2032 BGB oraz $\$ 550$ austriackiego kc.), jak również rozwiązania pośrednie, będące modyfikacją jednego z tych dwóch systemów. Przykładem tej ostatniej grupy może być regulacja obowiązująca w Polsce (art. 1035 i nast. kc. ${ }^{1}$ ), która jest zmodyfikowaną wersją systemu współwłasności ułamkowej². Jak podkreśla się w doktrynie, prawo spadkowe jest tą dziedziną prawa prywatnego, które spełnia swe funkcje społeczno-gospodarcze, dopiero przez dział spadku, od chwili jego dokonania, a więc od chwili, gdy określone ułamkowo części spadku przypadające poszczególnym spadkobiercom materializują się stosownie do ich wielkości, czyli każdy ze spadkobierców efektywnie otrzymuje to, co dotąd miał oznaczone idealnie ${ }^{3}$. Wśród przepisów dotyczących działu spadku (art. 1035-1046 kc.) na dużą uwagę zasługuje regulacja zamieszczona w art. 1039 kc., czyli instytucja zaliczenia darowizn i zapisów windykacyjnych na schedę spadkową spadkobiercy. W dalszej części artykułu skupię się w głównej mierze na przedstawieniu oraz analizie kontrowersji występujących na tle powyższej instytucji, jak również przedstawię własne uwagi de lege lata i de lege ferenda.

\section{Rys historyczny oraz cele instytucji zaliczenia darowizn i zapisów windykacyjnych na schedę spadkową}

Pierwowzoru normatywnego obecnych przepisów regulujących instytucję zaliczenia darowizn i zapisów windykacyjnych na schedę spadkową zasadniczo doszukiwać się można w regulacji zamieszczonej w art. 63-67 Prawa spadkowego z 1946 r. $^{4}$ We wcześniejszym stanie prawnym analizowaną instytucję określano jako „wyrównanie przysporzeń".

Zgodnie z powyższymi przepisami, sąd z urzędu dokonywał wyrównań, czyli nie było konieczności, aby spadkobierca złożył w tym względzie stosowny wniosek. Za wystarczające uznawano jedynie przytoczenie okoliczności, które świadczyłyby o zachodzących przesłankach do wyrównania. Wyrównanie było tylko instytucją mającą charakter rachunkowy, stanowiącą podstawę do przeprowadzenia działu spadku. Należy podkreślić, że krąg spadkobierców zobowiązanych do wyrównania przysporzeń ograniczony był do zstępnych spadkodawcy, o ile dziedziczyli oni z ustawy (art. 63 $\S 1$ Prawa spadkowego).

1 Ustawa z dnia 23 kwietnia 1964 r. - kodeks cywilny (tekst jedn. Dz.U. z 2017 r. poz. 459 ze zm.).

2 M. Pazdan, Umowny dział spadku w prawie prywatnym międzynarodowym, (w:) Prace z prawa cywilnego, wydane dla uczczenia pracy naukowej Profesora Józefa Stanisława Piątowskiego, Wrocław 1985, s. 218 i n.

3 S. Wójcik, Glosa do postanowienia Sądu Najwyższego z dnia 5 lutego 2002 r., sygn. (II CKN 803/99), „Orzecznictwo Sądów Polskich” 2002, z. 12, poz. 162, s. 643. 
Dokonując analizy każdego przepisu prawa interpretator powinien zawsze dążyć do odszukania jego znaczenia, jakie chciał mu nadać ustawodawca. W tym celu nie można ograniczyć interpretacji jedynie do wykładni literalnej przepisu, bowiem może ona okazać się niewystarczająca, a w konsekwencji błędna. Respektując wynik dokonanej wykładni literalnej, należy wzbogacić go przede wszystkim o wykładnię celowościową, jak również wykładnię systemową. Tylko dokonanie kompletnej interpretacji, złożonej zarówno z wykładni literalnej, celowościowej, jak też systemowej, może być uznane za wystarczający zabieg w celu odszukania w danej normie prawdziwych intencji ustawodawcy.

Mając na uwadze powyższe wskazówki, w pierwszej kolejności należy przytoczyć główne cele instytucji zaliczenia darowizn i przysporzeń z tytułu zapisów windykacyjnych przy dziale spadku. W doktrynie jako podstawowy cel tej regulacji wymienia się przede wszystkim zrównanie pozycji prawnej spadkobierców, którzy bez odmiennej woli spadkodawcy, powinni być traktowani tak samo ${ }^{5}$. Ponadto przepis ten spełnia funkcję uniemożliwiającą ,wyprowadzanie" majątku spadkodawcy przed jego śmiercią ze szkodą dla zstępnych dziedziczących z ustawy ${ }^{6}$, a także wspomaga regulację dziedziczenia ustawowego $\mathrm{w}$ realizacji hipotetycznej woli spadkodawcy w stosunku do losów jego majątku po śmierci ${ }^{7}$. Podnosi się też, że powyższa regulacja stanowi odpowiedź prawodawcy na spotykane często w praktyce tzw. spłacanie spadkobierców za życia ${ }^{8}$.

\section{Kontrowersje na tle art. $1039 \mathrm{kc}$.}

Największe kontrowersje przy wykładni art. 1039 kc. zarówno w doktrynie, jak i orzecznictwie wydaje się, że występują na tle zakresu przedmiotowego obowiązku zaliczenia darowizn, a mówiąc inaczej dotyczą one interpretacji występującego w tym przepisie wyrażenia „darowizna”. W tym przedmiocie generalnie można zaobserwować dwa stanowiska, z których jedno jest przejawem prymatu wykładni literalnej terminu „darowizna”, podczas gdy drugie większy nacisk kładzie na ratio legis przepisu.

Zgodnie z pierwszym poglądem wykładni art. 1039 kc., obowiązek zaliczenia na schedę spadkową należy ograniczyć wyłącznie do klasycznie rozumianych darowizn (umowa darowizny uregulowana w art. 888-902 kc.). Zaliczeniu podlegają

5 E. Skowrońska-Bocian, Komentarz do Kodeksu cywilnego. Spadki, Warszawa 2011, s. 308; L. Stecki, Zaliczenie darowizn między spadkobiercami darczyńcy, „Acta Universitatis Nicolai Copernici Prawo" 1976, nr 75, s. 127; K. Osajda, (w:) K. Osajda (red.) Kodeks cywilny. Komentarz. Tom III. Spadki, Warszawa 2013, s. 1069.

6 J. Biernat, Z problematyki tzw. testamentu działowego w polskim prawie spadkowym, „Przegląd Sądowy" 2005, nr 4, s. 41.

7 Postanowienie SN z dnia 24 stycznia 2002 r., III CKN 503/00, Legalis; J. Kremis, R. Strugała, (w:) E. Gniewek, P. Machnikowski (red.), Kodeks cywilny. Komentarz, Warszawa 2016, s. 1929.

K. Osajda, (w:) Kodeks..., op. cit., s. 1070. 
wszystkie świadczenia na mocy umowy darowizny, nawet zawarte konkludentnie (art. $890 \$ 1$ kc.). Poza literalnym brzmieniem, za powyższym rozumieniem przepisu przemawia ponadto wyjątkowy charakter regulacji (exceptiones non sunt extendendae). Pogląd ten znalazł odzwierciedlenie w orzecznictwie Sądu Najwyższego w postanowieniu z dnia 6 marca 2002 r. ${ }^{9}$ oraz postanowieniu z dnia 13 października 1971 r. ${ }^{10} \mathrm{~W}$ pierwszym ze wskazanych orzeczeń Sąd Najwyższy uznał, że nie podlega zaliczeniu na poczet schedy spadkowej nieodpłatne świadczenie pracy spadkodawcy przy rozbudowie domu spadkobiercy. Z kolei w drugim orzeczeniu Sąd Najwyższy orzekł, że nie jest darowizną w myśl art. 1039 kc. przysporzenie otrzymane tytułem zapisu.

Natomiast według drugiego poglądu, u podstaw którego leży przede wszystkim cel regulacji art. 1039 kc., obowiązek zaliczenia na schedę spadkową dotyczy wszelkich otrzymanych przez spadkobiercę przysporzeń pod tytułem darmym. Zdaniem autorów tego poglądu zaliczeniu podlegać będą także przysporzenia niemające formy prawnej darowizny, o ile jednak zostały dokonane nieodpłatnie oraz intencją stron było dokonanie ich na poczet przyszłego spadku. Wydaje się, że interpretacja ta w sposób lepszy oddaje charakter niniejszej instytucji, uwzględniając w większym stopniu dorozumianą wolę spadkodawcy. Inne korzyści otrzymane przez spadkobiercę od spadkodawcy, które podlegają zaliczeniu, zostały wskazane bądź bezpośrednio przez ustawę (art. 1043 kc.), bądź wynikają one z wykładni poszczególnych przepisów. Przykładami zaliczenia innych korzyści na poczet schedy spadkowej są:

- nabycie nieruchomości przez spadkobiercę w drodze zasiedzenia, w sytuacji gdy posiadanie było wynikiem nieformalnego wydzielenia nieruchomości przez spadkodawcę lub nastąpił tzw. dział spadku za życia spadkodawcy ${ }^{11}$;

- nabycie nieruchomości należącej do spadku przez jednego ze spadkobierców w drodze uwłaszczenia na podstawie art. 1 ust. 2 ustawy o uregulowaniu własności gospodarstw rolnych ${ }^{12}$, gdy posiadanie było wynikiem nieformalnego wydzielenia nieruchomości przez spadkodawcę lub nastąpił tzw. dział spadku za życia spadkodawcy ${ }^{13}$;

- nabycie nieruchomości należącej do spadku przez jednego ze spadkobierców na podstawie art. 1 ust. 1 ustawy o uregulowaniu własności gospodarstw rolnych, jeżeli uzyskał on jej posiadanie przed 4 listopada 1971 r. na podstawie

9 Postanowienie SN z dnia 6 marca 2002 r., V CKN 876/00, Legalis.

10 Postanowienie SN z dnia 13 października 1971r., III CRN 297/71, OSN 1984, nr 7, poz. 108.

11 Postanowienie SN z dnia 15 listopada 1968 r., III CRN 257/68, OSPiKA 1970, poz. 5; uchwała SN z dnia 15 grudnia 1969 r., III CZP 12/69, OSNCP 1970, nr 3, poz. 39; postanowienie SN z dnia 24 stycznia 2002 r., III CKN 503/00, Legalis nr 53774.

12 Ustawa o uregulowaniu własności gospodarstw rolnych z dnia 26 października $1971 \mathrm{r}$, (Dz.U. z 1971 r. Nr 27, poz. 250).

13 Uchwała SN z dnia 7 grudnia 1983 r., III CZP 60/83, OSNCP 1984, nr 7, poz. 108; postanowienie SN z dnia 24 stycznia 2002 r., III CKN 503/00, Legalis nr 53774. 
zawartej ze spadkodawcą nieformalnej umowy darowizny albo na podstawie zawartej bez zachowania wymaganej formy umowy o dział spadku ${ }^{14}$;

- przekazanie nieodpłatnie gospodarstwa rolnego następcy będącemu zstępnym spadkodawcy (rolnika) w celu uzyskania emerytury lub renty ${ }^{15}$.

Najwięcej rozbieżności w doktrynie występuje na tle zaliczenia na schedę spadkową dyspozycji wkładem na wypadek śmierci. Wydaje się, iż w tej materii należy podzielić umiarkowany pogląd zaprezentowany przez S. Wójcika ${ }^{16}$, który podkreśla, że nie można w sposób jednolity i całkowity rozstrzygnąć tej kwestii. Rozstrzygając daną sprawę, należy przede wszystkim badać, jaka była intencja wkładcy. W zależności od okoliczności będzie można stwierdzić, czy dyspozycja wkładem bankowym podlega zaliczeniu na schedę spadkową, czy też nie. Pogląd ten jest uzasadniony tym bardziej, jeśli weźmie się pod uwagę zarówno podstawowe zasady prawa spadkowego (zasada prymatu woli spadkodawcy), jak również wspomniany wcześniej cel regulacji art. 1039 kc. (realizacja hipotetycznej woli spadkodawcy w stosunku do losów jego majątku po śmierci, zrównanie pozycji prawnej spadkobierców).

Wydaje się, że ustawodawca powinien rozważyć swoją ingerencję w treść art. 1039 kc., która miałaby na celu rozstrzygnięcie pojawiających się kontrowersji dotyczących zakresu przedmiotowego zaliczenia na schedę spadkową. Nie znajduję żadnych racjonalnych powodów, dla których zaliczeniu podlegałyby wyłącznie darowizny, podczas gdy inne przysporzenia na rzecz spadkobiercy pod tytułem darmym od tego obowiązku są zwolnione. Mają one nie tylko taki sam charakter jak darowizny w rozumieniu art. 888 kc., ale również zbliżony do nich cel. Z racji tego należy postulować de lege ferenda o rozszerzenie zakresu obowiązku zaliczenia na schedę spadkową na wszystkie nieodpłatne przysporzenia dokonane przez spadkodawcę na rzecz spadkobiercy.

Kolejną wątpliwością, jaka występuje w doktrynie na tle regulacji instytucji zaliczenia zapisów windykacyjnych i darowizn na poczet schedy spadkowej, jest pytanie, czy spadkodawca ma możliwość poprzez złożone oświadczenie rozszerzyć obowiązek zaliczenia na dokonane przez niego nieodpłatne świadczenia, które nie są darowizną. Mając na uwadze poprzednio poczynione uwagi, wydaje się, że taką możliwość należy dopuścić. Jeśli za dozwolone zostało uznane zaliczanie przysporzeń niebędących stricte darowiznami w rozumieniu kodeksu cywilnego, to tym bardziej powinny być zaliczane na schedę spadkową przysporzenia pod tytułem darmym inne niż darowizny, jeśli wolę takiego zaliczenia wyraził spadkodawca. Wydaje się, że zmiana tre-

14 Postanowienie SN z dnia 23 października 1975 r., III CRN 281/75, OSNCP 1976, nr 10, poz. 212.

15 Postanowienie Sądu Najwyższego z dnia 24 stycznia 2002 r., III CKN 503/00, Legalis nr 5377.

16 S. Wójcik, (w:) J.S. Piątowski (red.), System Prawa Cywilnego. T. IV. Prawo spadkowe, Wrocław 1986, s. 474. 
ści art. 1039 kc. we wskazany w poprzednim akapicie sposób usunęłaby wątpliwości również w niniejszej kwestii.

Zgodnie z treścią art. $1039 \$ 1$ kc., obowiązek zaliczenia darowizn i zapisów windykacyjnych zależy de facto od woli spadkodawcy, ponieważ jest on upoważniony czy to w umowie darowizny lub testamencie - do zwolnienia obdarowanego danym przysporzeniem od tego obowiązku. Spadkodawca klasyczną sytuację w przedmiocie obowiązku zaliczenia darowizn i zapisów windykacyjnych może modyfikować również w przeciwnym kierunku, poprzez zobowiązanie innych spadkobierców ustawowych do zaliczenia otrzymanych od niego darowizn lub zapisów windykacyjnych (art. $1039 \$ 2$ kc.). Powszechnie akceptowalne w doktrynie jest stanowisko, zgodnie z którym spadkodawca może zwolnić od obowiązku zaliczenia darowizn lub zapisów windykacyjnych na schedę spadkową zarówno wszystkich, na których taki obowiązek ciąży, jak i wyłącznie wybrane osoby z tego kręgu. Identycznie sytuacja kształtuje się w przypadku oświadczenia nakładającego obowiązek zaliczenia na schedę spadkową darowizny lub zapisu windykacyjnego na innego spadkobiercę ustawowego. Spadkodawca zatem może w dość swobodny sposób kształtować treść obu swoich oświadczeń. Niemniej jednak, tego rodzaju oświadczenie spadkodawcy wpływa jedynie na sposób działu spadku, natomiast nie można ich traktować jako rozporządzenie majątkiem spadkowym.

Mając na względzie powyższe uwagi dotyczące oświadczenia woli spadkodawcy w przedmiocie zwolnienia darowizny lub przysporzenia $z$ tytułu zapisu windykacyjnego z obowiązku zaliczenia do spadku na potrzebę jego działu oraz w przedmiocie nałożenia na spadkobiercę obowiązku zaliczenia w takiej sytuacji dokonanej darowizny lub przysporzenia $\mathrm{z}$ tytułu zapisu windykacyjnego, można wysunąć wniosek, że istnieje możliwość, aby spadkodawca w treści swojego oświadczenia ograniczył zakres zwolnienia lub obowiązek zaliczenia. Jak zostało to podkreślone, spadkodawca w sposób zupełnie dowolny ma możliwość kształtowania treści powyższych oświadczeń. Nie ma zatem żadnych przeciwwskazań, aby swoboda w kształtowaniu treści oświadczenia nie rozciągała się również na zakres zwolnienia czy obowiązku zaliczenia. Wydaje się zatem, że spadkodawca może w swoim oświadczeniu stwierdzić, że zaliczeniu podlegać będzie tylko część dokonanej na rzecz spadkobiercy ustawowego darowizny lub zapisu windykacyjnego. Analogicznie sytuacja powinna kształtować się w przypadku nałożenia obowiązku zaliczenia na innych spadkobierców ustawowych - spadkodawca ma swobodę w określaniu, czy zaliczeniu podlegać będzie całość dokonanej darowizny (zapisu windykacyjnego), czy tylko jej część. Z praktycznego punktu widzenia, powyższe ograniczenie może przybrać dwie formy. Przede wszystkim spadkodawca może ograniczyć zwolnienie albo nałożenie obowiązku zaliczenia darowizny lub przysporzenia z tytułu zapisu windykacyjnego w sposób procentowy, np. spadkodawca stwierdza, że tylko 50\% wartości przedmiotu darowizny (zapisu windykacyjnego) będzie podlegało zaliczeniu na przypadającą spadkobiercy schedę spadkową. Większe wątpliwości mogą pojawić się w przypadku drugiego spo- 
sobu ograniczenia, czyli ograniczenia kwotowego, np. spadkobierca oświadcza, że zaliczeniu podlegać będzie przedmiot darowizny jedynie do kwoty 500 zł. Problem, jaki może mieć miejsce przy tym sposobie ograniczenia zaliczenia wartości przedmiotu darowizny lub zapisu windykacyjnego to fakt, że wartość przedmiotu darowizny zgodnie z art. $1042 \$ 2$ kc. - oblicza się według stanu z chwili jej dokonania, a według cen $\mathrm{z}$ chwili działu spadku. Biorąc pod uwagę, że oświadczenie spadkodawcy może zostać złożone w długim odstępie czasu od chwili działu spadku, istnieje ryzyko, iż podane w oświadczeniu kwotowe ograniczenie nijak się będzie miało do wartości, jaką ma przedmiot w momencie działu spadku. Z racji na tą okoliczność, bardziej wskazane jest posługiwanie się przez spadkodawcę ograniczeniem procentowym (ułamkowym). Natomiast, jeśli będzie miało miejsce ograniczenie kwotowe, należałoby je przekształcić w ograniczenie procentowe poprzez obliczenie stosunku wartości ograniczenia do wartości całego przedmiotu darowizny. Wydaje się, że powyższy schemat należy powielić w przypadku zapisu windykacyjnego z uwzględnieniem treści art. $1042 \$ 2^{1} \mathrm{kc}$. Przedstawiony przeze mnie pogląd, mimo braku w tym względzie wypowiedzi judykatury czy przedstawicieli doktryny, jest w pełni dopuszczalny, gdy weźmie się również cel regulacji art. 1039 kc., a także zasadę prawa spadkowego, czyli prymatu woli spadkodawcy.

W przedmiocie oświadczenia spadkodawcy nakładającego obowiązek zaliczenia darowizn i przysporzeń z tytułu zapisu windykacyjnego należy podkreślić, że zgodnie z obowiązującym obecnie art. $1039 \$ 2 \mathrm{kc}$. powyższy obowiązek może być nałożony jedynie na spadkobierców ustawowych. De lege lata nie jest możliwe, aby spadkodawca obowiązkiem zaliczenia darowizn (zapisów windykacyjnych) obciążył również spadkobierców testamentowych. W doktrynie ${ }^{17}$ wyrażany jest słuszny pogląd kwestionujący zasadność takiej regulacji. Jako argumenty przemawiające za rozszerzeniem zakresu art. $1039 \$ 2$ kc. o spadkobierców testamentowych wymienia się przede wszystkim walor praktyczny (brak konieczności zmiany testamentu po późniejszym dokonaniu darowizny) oraz poszerzenie zakresu dopuszczalnych dyspozycji mortis causa. Nie ma też żadnych powodów uzasadniających różnicowanie w tym względzie spadkobierców testamentowych i spadkobierców ustawowych.

Zgodnie z treścią art. $1039 \$ 3 \mathrm{kc}$. zaliczeniu na schedę spadkową nie podlegają drobne darowizny przyjęte zwyczajowo w danych stosunkach. Podkreśla się, że powyższa regulacja dotyczy przede wszystkim darowizn dokonywanych z okazji świąt, urodzin, imienin, ślubu lub innego zdarzenia o charakterze osobistym ${ }^{18}$. Z uwagi, że ustawodawca w powyższym przepisie posłużył się terminem nieostrym, ocena, czy

17 K. Osajda, (w:) Kodeks..., op. cit., s. 1072.

18 M. Pazdan, (w:) K. Pietrzykowski (red.), Kodeks cywilny. Tom II. Komentarz. Art. 450-1088, Warszawa 2015, s. 1190. 
chodzi o darowiznę drobną, będzie zależeć od okoliczności konkretnego przypadku (np. stan majątkowy spadkodawcy i obdarowanego $)^{19}$.

$\mathrm{Na}$ tle tego przepisu wyrażane jest zapatrywanie ${ }^{20}$, że regulacja zwalniająca z obowiązku zaliczenia na schedę spadkową jedynie drobne darowizny ma zbyt wąski zakres - powinna być rozszerzona o drobne przysporzenia $\mathrm{z}$ zapisów windykacyjnych. Pogląd ten wydaje się być uzasadniony, gdy weźmie się pod uwagę fakt, że zaliczeniu podlegają wszystkie przedmioty zapisu windykacyjnego - nawet drobne podczas gdy tego rodzaju darowizny z takiego obowiązku są zwolnione. Nowelizacja przepisu jest tym bardziej uzasadniona, jeśli zauważymy, że de facto cel drobnych darowizn i zapisów windykacyjnych jest tożsamy.

Zbliżoną instytucją do zaliczenia darowizn i zapisów windykacyjnych na schedę spadkową jest zaliczenie darowizn i zapisów windykacyjnych na potrzeby ustalenia wysokości należnego zachowku (art. 993-997 kc.). Jedną z podstawowych różnic, jakie występują pomiędzy obiema regulacjami, jest to, że przy dziale spadku doliczeniu podlegają wszystkie dokonane przez spadkodawcę darowizny bez względu na to, kiedy zostały dokonane, podczas gdy przy doliczaniu darowizn dla potrzeb obliczania należnego zachowku zaliczeniu podlegają jedynie darowizny, które były dokonane przed mniej niż dziesięciu laty przed otwarciem spadku, jeśli zostały dokonane na rzecz osób trzecich, tj. innych niż spadkobiercy i uprawnieni do zachowku, a przy obliczaniu zachowku należnego zstępnemu nie dolicza się do spadku darowizn uczynionych przez spadkodawcę w czasie, kiedy nie miał zstępnych; zaś jedynie przy obliczaniu zachowku należnego małżonkowi nie dolicza się do spadku darowizn, które spadkodawca uczynił przed zawarciem z nim małżeństwa (art. 994 kc.).

$\mathrm{W}$ doktrynie ${ }^{21}$ wyrażany jest pogląd de lege ferenda, że podobne ograniczenie czasowe, jakie ma miejsce przy zaliczaniu darowizn i zapisów windykacyjnych na potrzeby ustalania wysokości należnego zachowku, powinno być wprowadzone również w kontekście zaliczania powyższych przysporzeń na schedę spadkową. Jako argument za taką zmianą przytacza się sytuację, kiedy to spadkodawca wiele (40) lat przed otwarciem spadku dokonuje darowizny na rzecz swojego zstępnego. Wedle tej opinii, taka darowizna nie może być traktowana jako „spłacenie” z majątku rodzinnego konkretnego spadkobiercy. W moim przekonaniu, powyższy pogląd należy uznać za błędny, bowiem stoi on w oczywistej sprzeczności w stosunku do celów regulacji z art. $1039 \mathrm{kc}$. Taka interpretacja przedstawionej sytuacji prowadziłaby do nieuzasadnionego faworyzowania jednego spadkobiercy kosztem pozostałych. Dodatkowo podkreślić trzeba, że w przypadku, gdy spadkodawca ma kilku zstępnych i tylko na rzecz jednego z nich dokonuje wartościowej darowizny, wydaje się, iż jego

19 E. Skowrońska-Bocian, Komentarz..., op. cit., s. 310; J. Kremis, R. Strugała, (w:) Kodeks..., op. cit., s. 1931.

20 P. Księżak, Zapis windykacyjny, Warszawa 2012, s. 173; K. Osajda, (w:) Kodeks..., op. cit., s. 1072.

21 K. Osajda, (w:) Kodeks..., op. cit., s. 1070. 
„typową” intencją byłoby właśnie traktowanie tej darowizny jako „spłatę za życia”, nawet jeśli darowizna miałaby miejsce wiele lat przed śmiercią spadkodawcy.

Kontrowersje na tle zaliczenia darowizn i zapisów windykacyjnych na schedę spadkową występują również w przypadku częściowego działu spadku. Pozostaje dyskusyjne w doktrynie, czy powyższe zaliczenie może mieć miejsce w postępowaniu działowym ograniczonym do części spadku, a jeśli tak, to w jaki sposób należy dokonać zaliczenia.

Część autorów ${ }^{22}$ uznaje, że częściowy dział spadku jest niedozwolony w sytuacji, gdy zostanie zgłoszone żądanie zaliczenia darowizn na schedę spadkową. Przeciwnicy $^{23}$ tego poglądu podnosili z kolei, że przedstawione stanowisko nie znajduje wystarczającego oparcia w obowiązujących przepisach - art. $1042 \$ 1$ in principio kc. nie wyklucza zaliczenia darowizn także w postępowaniu działowym ograniczonym do części spadku.

Są również dwie koncepcje sposobu zaliczenia darowizn w sytuacji częściowego działu spadku. Zgodnie z pierwszym pomysłem, do podlegającej podziałowi części spadku należy doliczyć proporcjonalną część wartości przedmiotu darowizny, następnie wartość tej części zaliczyć na schedę zobowiązanego spadkobiercy ${ }^{24}$. Inna koncepcja zakłada z kolei, że istnieje możliwość doliczenia do części dzielonego spadku całej wartości przedmiotu darowizny z zaliczeniem pełnej wartości na schedę obdarowanego spadkobiercy ${ }^{25}$. Wydaje się, iż obie metody są dopuszczalne, ale nie można pominąć faktu, że drugi sposób nie powoduje aż tak licznych komplikacji jak pierwszy. Niemniej jednak, to od sądu oraz od woli uczestników postępowania powinno zależeć, który z powyższych sposobów znajdzie w danej sprawie zastosowanie.

\section{Podsumowanie}

Wydaje się, że choć instytucja zaliczenia darowizn i zapisów windykacyjnych na schedę spadkową nie należy do grupy przepisów polskiego prawa, która wymagałaby natychmiastowej ingerencji ustawodawcy, ale odnotować należy, iż istnieje wiele racjonalnych argumentów przemawiających za tym, aby powyższą regulację zmodyfikować. Ewentualna przyszła nowelizacja art. 1039 kc. może obrać jeden z następujących kierunków: usunięcie obowiązku zaliczenia darowizn i zapisów windykacyjnych na schedę spadkową albo odwrócenie mechanizmu działania badanej instytucji przez przyjęcie, że darowizny i zapisy windykacyjne będą podlegać zaliczeniu jedynie, gdy

22 L. Stecki, Zaliczenie..., op. cit., s. 128.

23 A. Stempniak, Postępowanie w sprawach o dział spadku. Komentarz oraz wzory pism procesowych i orzeczeń sądowych, Warszawa 2012, s. 308-309.

24 S. Wójcik, (w:) System..., op. cit., s. 471.

25 A. Stempniak, Postępowanie..., op. cit., s. 309. 
taka będzie wola spadkodawcy ${ }^{26}$. Można również sobie wyobrazić, że byłaby to nowelizacja miająca charakter bardziej kosmetyczny, polegająca na uwzględnieniu poszczególnych uwag zawartych w artykule, które nie zmieniałyby dotychczasowych podstawowych zasad w tym zakresie.

\section{BIBLIOGRAFIA}

Biernat J., Z problematyki tzw. testamentu działowego w polskim prawie spadkowym, „Przegląd Sądowy" 2005, $\mathrm{nr} 4$.

Fras M., Dział spadku. Uwagi de lege lata i de lege ferenda, „Rejent” 2006, nr 2.

Kremis J., Strugała R., (w:) E. Gniewek, P. Machnikowski (red.), Kodeks cywilny. Komentarz, Warszawa 2011.

Księżak P., Zapis windykacyjny, Warszawa 2012.

Osajda K., (w:) K. Osajda (red.), Kodeks cywilny. Komentarz. Tom III. Spadki, Warszawa 2013.

Pazdan M., (w:) K. Pietrzykowski (red.), Kodeks cywilny. Tom II. Komentarz. Art. 450-1088, Warszawa 2015.

Pazdan M., Umowny dział spadku w prawie prywatnym międzynarodowym, (w:) Prace z prawa cywilnego, wydane dla uczczenia pracy naukowej Profesora Józefa Stanisława Piątowskiego, Wrocław 1985.

Skowrońska-Bocian E., Komentarz do Kodeksu cywilnego. Spadki, Warszawa 2011.

Stecki L., Zaliczenie darowizn między spadkobiercami darczyńcy, „Acta Universitatis Nicolai Copernici Prawo" 1976, nr 75.

Stempniak A., Postępowanie w sprawach o dział spadku. Komentarz oraz wzory pism procesowych i orzeczeń sądowych, Warszawa 2012.

Wójcik S., (w:) J.S. Piątowski (red.), System Prawa Cywilnego. T. IV. Prawo spadkowe, Wrocław 1986.

Wójcik S., Glosa do postanowienia Sądu Najwyższego z dnia 5 lutego 2002 r., sygn. (II CKN 803/99), „Orzecznictwo Sądów Polskich” 2002, z. 12, poz. 162. 